\title{
PENGHAMBATAN AKTIVITAS XANTHINE OXIDASE OLEH EKSTRAK ETANOL AKAR SAMBILOTO (Andrographis paniculata,Ness) SECARA IN VITRO
}

\section{XANTHINE OXIDASE INHIBITORY OF ETHANOLIC EXTRACT OF SAMBILOTO ROOT}

\author{
Ulfah Septianingsih, Hari Susanti, Wahyu Widyaningsih \\ Fakultas Farmasi Universitas Ahmad Dahlan \\ Jl Prof Dr Soepomo Yogyakarta, Telp. (0274) 379418
}

\begin{abstract}
Abstrak
Tanaman Sambiloto merupakan salah satu tanaman yang mengandung flavonoid yang digunakan masyarakat untuk pengobatan tradisional. Dari penelitian terdahulu dilaporkan bahwa senyawa flavonoid dapat berpotensi menurunkan kadar asam urat darah dengan cara menghambat aktivitas xanthine oxidase. Oleh karena adanya flavonoid yang terkandung dalam akar Sambiloto maka dilakukan penelitian apakah ekstrak etanol akar Sambiloto dapat menghambat aktivitas xanthine oxidase. Sebagai pembanding digunakan Allopurinol. Ekstrak etanol dibuat dari serbuk akar Sambiloto diekstraksi dengan etanol menggunakan metode penyarian dengan alat Soxhlet, sebelum penyarian dilakukan pengawalemakan menggunakan petroleum eter. Penghambatan aktivitas xanthine oxidase oleh ekstrak etanol akar Sambiloto ditentukan melalui penurunan produksi asam urat yang dimonitor dengan spektrofotometer pada $295 \mathrm{~nm}$ dengan xanthine sebagai substrat. Nilai kecepatan yang diperoleh selanjutnya digunakan untuk menghitung nilai aktivitas. Kemudian ditentukan konsentrasi ekstrak etanol yang mampu menghambat aktivitas xanthine oxidase sebesar 50\% (IC50). Hasil dianalisis secara kuantitatif, dengan menggunakan uji Kruskal Wallis dengan taraf kepercayaan 95\%, kemudian dilanjutkan dengan uji Mann Withney. Flavonoid dalam ekstrak etanol dipisah dengan cara kromatografi kertas dan perubahan bercak ditentukan dengan UV 366 dengan dan tanpa pemberian uap amoniak. Hasil penelitian menunjukkan bahwa ekstrak etanol akar Sambiloto menghambat aktivitas Xanthine Oxidase dengan $I C_{50} \quad 16,82 \mu \mathrm{g} / \mathrm{ml}$ sedangkan $I C_{50}$ Allopurinol adalah 4,29 $\mu \mathrm{g} / \mathrm{ml}$. Ekstrak etanol akar Sambiloto diduga mengandung flavonoid golongan flavon atau flavonol.
\end{abstract}

Kata Kunci : akar Sambiloto, xanthine oxidase, asam urat. 


\section{Abstract}

Sambiloto root of which contained of flavonoids used by the people for traditional medicine. In the previous publication, an effective xanthine oxidase inhibitory activity of flavonoids was reported. In research, in vitro xanthine oxidase inhibitory activity of etanolic root extract of Andrographis paniculata was determined and Allopurinol was used as a control. The etanolic extract was succesively extracted in a Soxhlet with petroleum eter. Inhibition of xanthine oxidase by etanolic extract was measured the decrease of uric acid production and monitored by spectrophotometer at $295 \mathrm{~nm}$ with xanthine as substrat. The enzyme inhibitory activity was calculated, and then $I C_{50}$ was determined. The result of analyzed with Kruskal Wallis and Mann Whitney at $95 \%$ confidental level. The flavonoids of etanolic extract were separated on using by paper chromatography and the spot changing was determined using UV 366 with and without amonia.The result of the research showed that the etanolic extract of Andrographis paniculata inhibited xanthine oxidase activity with $I_{50} 16,54 \mu \mathrm{g} / \mathrm{ml}$ while Allopurinol 4,29 $\mathrm{g} / \mathrm{ml}$. The etanolic extract contained flavon or flavonol.

Keywords : Andrographis paniculata, Ness, xanthine oxidase, uric acid.

\section{PENDAHULUAN}

Di Indonesia, untuk penyakit reumatik, gout menduduki peringkat kedua terbanyak setelah osteoarthritis. Gout terjadi bila timbunan kristal monosodium urat monohidrat (MSU) di persendian meningkat. Timbunan kristal ini menimbulkan peradangan jaringan yang memicu timbulnya reumatik gout akut (Dalimartha, 2001).

Secara alami, asam urat diproduksi dalam tubuh melalui jalur metabolisme yang menggunakan makanan dan minuman sebagai substrat. Mengkonsumsi makanan dengan kandungan purin tinggi seperti kacang-kacangan, melinjo atau emping, jeroan, dan minuman yang mengandung kafein seperti kopi, teh serta kola dapat menaikkan kadar asam urat dalam darah (Sustrani dkk, 2005).
Biasanya penyakit gout diatasi dengan memberikan obat-obat sintetik baik itu urikosurik maupun urikostatik (Allopurinol) (Dewani dan Sitanggang, 2006). Penggunaan Allopurinol dapat menimbulkan efek samping mual, muntah dan diare dapat juga terjadi neuritis perifer, depresi unsur sumsum tulang belakang dan kadang-kadang anemia aplastika. Dilaporkan juga terjadi toksisitas hati dan nefritis intestinal. Allopurinol juga dapat terikat ke lensa mata yang akan menyebabkan katarak (Katzung, 1995). Oleh karena itu orang-orang mencari alternatif baru dengan mengembangkan penggunaan obat tradisional yang cenderung lebih aman. Salah satu tanaman yang mudah untuk ditemukan yaitu Sambiloto (Andrographis paniculata, Ness.). Sambiloto dikenal secara luas baik di kalangan pengguna tanaman obat, 
pembuat jamu, pengobat tradisional dan peneliti tanaman obat. Tanaman ini terdapat di seluruh Indonesia. Hal ini terbukti dengan adanya nama daerah yang berbeda-beda, seperti Sambilata (Melayu), Ampadu Tanah (Sumatra Barat), Ki Oray (Jawa Barat), Sambiloto (Jawa Tengah), dan Papaitan (Madura) (Syamsuhidayat dan Hutapea, 1991).

Daun Sambiloto mengandung flavonoid turunan flavon, yaitu 4' hidroksi flavon (Setiyaningsih 2003). Flavonoid diisolasi terbanyak dari akar (Wijayakusuma, 1993). Beberapa senyawa flavonoid dan alkaloid dapat menghambat kerja enzim Xanthine Oxidase sehingga dapat menghambat pembentukan asam urat dalam tubuh (Cos dkk,1998). (Cos dkk,1998). Berkaitan dengan keberadaan flavonoid di dalam tanaman Sambiloto, perlu dilakukan usaha untuk mengetahui lebih jauh mengenai kemampuan akar Sambiloto dalam penghambatan aktivitas xanthine oxidase

Dari hasil penelitian ini apabila hasilnya baik maka diharapkan dapat memberikan wawasan kepada masyarakat umum bahwa penyakit asam urat dapat diobati dengan cara yang mudah yaitu dengan menggunakan akar Sambiloto.

\section{METODE PENELITIAN}

\section{Bahan}

Akar Sambiloto dikumpulkan dari daerah Kulon Progo Yogyakarta pada bulan Mei 2007. xanthine oxidase dan Xanthine diperoleh dari Sigma Chemical Co; Allopurinol kualitas farmasetis diperoleh dari Dexa Medica, Petroleum eter, dimetilsulfoksida (DMSO), etanol, asam asetat glasial, kalium dihidrogen fosfat, natrium hidroksida, diperoleh dari E.Merck, Aquadestilata diperoleh dari CV. Multi Kimia, Aquabidestilata diperoleh dari PT Ikapharmindo Putramas.

\section{Alat}

Spektrofotometer Shimadzu Pharmaspec UV 1700, seperangkat alat Soxhlet (Scott), pH meter ORION, rotary evaporator, neraca analitik (Sartorius), mikro pipet (Soccorec), ephendroff, seperangkat alat kromatogafi kertas, ultrasonic dan alat-alat gelas yang lazim.

\section{Jalannya Penelitian}

\section{a. Pembuatan ekstrak etanol}

Akar Sambiloto dikeringkan di bawah sinar matahari dengan ditutup kain hitam, sampai kering. Setelah kering diserbuk dengan menggunakan blender. Ekstrak etanol dibuat dengan menggunakan alat Soxhlet. Seratus dua puluh lima gram serbuk akar Sambiloto yang telah ditimbang seksama dibungkus dengan kertas saring dan dimasukkan ke dalam tabung Soxhlet. Kemudian dilakukan pengawalemakan dengan petroleum eter dan disari dengan etanol sampai cairan yang mengalir dari rumah siput tidak berwarna lagi. Ekstrak etanol yang diperoleh dipekatkan dengan rotary evaporator pada suhu $75^{\circ} \mathrm{C}$. Setelah itu ekstrak kental dikeringkan menggunakan oven dengan suhu $45^{\circ} \mathrm{C}$ hingga bobot konstan. Hasil akhir dari penyarian ini adalah ekstrak kental dengan bobot 8,01 gram. 
b. Pembuatan larutan xanthine 100 $\mu \mathrm{g} / \mathrm{ml}$.

Xanthine murni ditimbang sebanyak 100 mg. kemudian dilarutkan dengan beberapa tetes $\mathrm{NaOH} 0,01 \mathrm{~N}$, kemudian disonifikasi sampai larut (jika perlu ditambahkan beberapa tetes $\mathrm{NaOH} 0,2$ $\mathrm{N}$, lalu ditambah dapar fosfat sampai 100,0 $\mathrm{ml}$ sehingga diperoleh konsentrasi $1 \mathrm{mg} / \mathrm{ml}$. Dari larutan xanthine $1 \mathrm{mg} / \mathrm{ml}$ diambil 1,0 ml kemudian ditambah dapar fosfat sampai $10,0 \mathrm{ml}$ untuk membuat larutan xanthine konsentrasi $100 \mu \mathrm{g} / \mathrm{ml}$.

c. Pembuatan larutan xanthine oxidase $50 \mathrm{mU} / \mathrm{ml}$.

Xanthine oxidase sebanyak 25 unit dilarutkan dalam $10 \mathrm{ml}$ dapar fosfat $\mathrm{pH}$ 7,5 sehingga diperoleh konsentrasi 2,5 unit $/ \mathrm{ml}$ (larutan I). Dari larutan I diambil 1,0 ml, kemudian ditambah dapar fosfat $\mathrm{pH} \quad 7,5$ sampai $25,0 \mathrm{ml}$ sehingga diperoleh konsentrasi $100 \mathrm{mU} / \mathrm{ml}$ (larutan II). Untuk membuat larutan xanthine oxidase konsentrasi $50 \mathrm{mU} / \mathrm{ml}$, dari larutan II diambil 5,0 ml kemudian ditambah dapar fosfat $\mathrm{pH} 7,5$ sampai $10,0 \mathrm{ml}$.

d. Pembuatan larutan induk (larutan uji).

Ekstrak etanol dijadikan larutan induk dengan cara melarutkan 100,0 mg ekstrak etanol dengan beberapa tetes DMSO, kemudian ditambah dapar fosfat $\mathrm{pH} \quad 7,5$ sampai volume $100,0 \mathrm{ml}$ sehingga diperoleh konsentrasi $1 \mathrm{mg} / \mathrm{ml}$. Dari larutan induk $(1 \mathrm{mg} / \mathrm{ml})$ dibuat larutan uji dengan konsentrasi $10 \mu \mathrm{g} / \mathrm{ml}$, $15 \mu \mathrm{g} / \mathrm{ml}$, dan $20 \mu \mathrm{g} / \mathrm{ml}$.

e. Pembuatan larutan pembanding Allopurinol.

Larutan pembanding Allopurinol dibuat dengan cara melarutkan $100 \mathrm{mg}$ Allopuriol dengan air bebas $\mathrm{CO}_{2}$ sampai volume $250 \mathrm{ml}$ sehingga diperoleh konsentrasi $400 \mu \mathrm{g} / \mathrm{ml}$. Dari larutan 400 $\mu \mathrm{g} / \mathrm{ml}$ dibuat larutan pembanding Allopurinol dengan konsentrasi antara $10 \mu \mathrm{g} / \mathrm{ml}$ sampai $100 \mu \mathrm{g} / \mathrm{ml}$. Dari konsentrasi $100 \mu \mathrm{g} / \mathrm{ml}$ dibuat larutan dengan konsentrasi antara $2,5 \mu \mathrm{g} / \mathrm{ml}, 5$ $\mu \mathrm{g} / \mathrm{ml} ; 7,5 \mu \mathrm{g} / \mathrm{ml}$ dan $10 \mu \mathrm{g} / \mathrm{ml}$.

f. Penentuan aktivitas xanthine oxidase

Aktivitas xanthine oxidase ditentukan dengan menambahkan $200 \mu \mathrm{l}$ substrat (xanthine) $\quad 100 \quad \mu \mathrm{g} / \mathrm{ml} \quad \mathrm{ke}$ dalam campuran $100 \mu \mathrm{l}$ xanthine oxidase 50 $\mathrm{mU} / \mathrm{ml}$ dan $724 \mu \mathrm{l}$ bufer fosfat $\mathrm{pH}$ 7,5. aktivitas xanthine oxidase ditentukan dengan mengamati kecepatan pembentukan asam urat dari Xanthine secara spektrofotometri pada $\lambda 295 \mathrm{~nm}$ dari menit ke-0 sampai menit ke-3 pada suhu $25^{\circ} \mathrm{C}$. Data yang diperoleh adalah berupa rate ( $\Delta$ A295/menit).

g. Penentuan penghambatan aktivitas xanthine oxidase

Penghambatan aktivitas xanthine oxidase dilakukan penambahan $200 \mu \mathrm{l}$ larutan uji menggunakan konsentrasi 10 $\mu \mathrm{g} / \mathrm{ml}, 15 \mu \mathrm{g} / \mathrm{ml}$ dan $20 \mu \mathrm{g} / \mathrm{ml} \mathrm{ke}$ dalam campuran bufer fosfat dan xanthine oxidase. Dengan cara yang sama, ditentukan pula penghambatan aktivitas 
xanthine oxidase oleh $200 \mu 1$ allopurinol menggunakan konsentrasi $2,5 \mu \mathrm{g} / \mathrm{ml}, 5$ $\mu \mathrm{g} / \mathrm{ml}, 7,5 \mu \mathrm{g} / \mathrm{ml}$ dan $10 \mu \mathrm{g} / \mathrm{ml}$.

h. Identifikasi flavonoid dalam ekstrak etanol akar Sambiloto

Identifikasi adanya flvonoid dalam ekstrak etanol akar Sambiloto dilakukan dengan uji pendahuluan dan pemeriksaan kromatografi kertas. Uji pendahuluan dilakukan dengan cara memberi uap amonia pada tetesan kering larutan ekstrak etanol dalam etanol pada kertas Whatman. Bercak berwarna kuning menunjukkan adanya flavonoid. Pemeriksaan kromatografi kertas untuk mengetahui bercak warna dan pemisahan flavonoid yang terdapat pada larutan ekstrak etanol dalam etanol dengan cara kromatografi kertas dengan fase gerak n-butanol-asam asetat-air (4:1:5) fase atas. Warna dan perubahan warna bercak dengan dan tanpa amoniak diperiksa menggunakan lampu UV 366.

\section{Analisis Data}

Data yang diperoleh berupa hasil pengukuran terapan secara spektrofotometri UV yaitu $\Delta \mathrm{A}_{295} /$ menit dan besarnya aktivitas enzim dihitung dengan rumus:

Aktivitas (unit $/ \mathrm{ml}$ enzim $)=1,024$ adalah volume total campuran (ml), 12,2 adalah koefisien ekstingsi asam urat $(\mathrm{mM}), 0,1$ adalah volume enzim yang digunakan (ml).

Aktivitas enzim dapat dinyatakan dalam satuan yang lain dan dihitung dengan rumus :
Unit/mg solid $=\frac{\text { unit } / \mathrm{ml} \text { enzim }}{\mathrm{mg} \text { solid } / \mathrm{ml} \text { enzim }}$

Hasil digunakan untuk menghitung persentase penghambatan xanthine oxidase dengan rumus:

$\%$ inhibisi $=\frac{\text { aktivitas tanpa bahan uji }- \text { aktivitas bahan uji }}{\text { aktivitas tanpa bahan uji }} \times 100 \%$

Nilai $I C_{50}$ (konsentrasi inhibitor yang menghasilkan penghambatan aktivitas xanthine oxidase sebesar 50\%) dapat ditentukan dengan analisis regresi linier antara konsentrasi senyawa uji terhadap persentase penghambatan aktivitas xanthine oxidase.

\section{HASIL DAN PEMBAHASAN}

\section{Penentuan aktivitas xanthine oxidase}

Penelitian ini bertujuan untuk mengetahui kemampuan sediaan uji yaitu ekstrak etanol akar Sambiloto dibandingkan Allupurinol dalam menghambat aktivitas enzim xanthine oxidase secara in vitro.

Aktivitas xanthine oxidase ditentukan secara spektrofotometri dengan mengamati kecepatan pembentukan asam urat pada $\lambda 295 \mathrm{~nm}$. xanthine mempunyai serapan disekitar $\lambda 260 \mathrm{~nm}$ (Nagao dkk, 1999). Menurut Van Hoorn dkk (2002) selama 6 menit kinetika reaksi adalah linier. Kecepatan pembentukan asam urat pada penelitian ini linier sampai menit ke-3. Kurva mulai landai pada menit ke-4, sehingga untuk penelitian selanjutnya hanya dilakukan pada menit ke-0 sampai ke-3. Edmondson dkk (1972) mengusulkan mekanisme reaksi katalisis oleh xanthine 


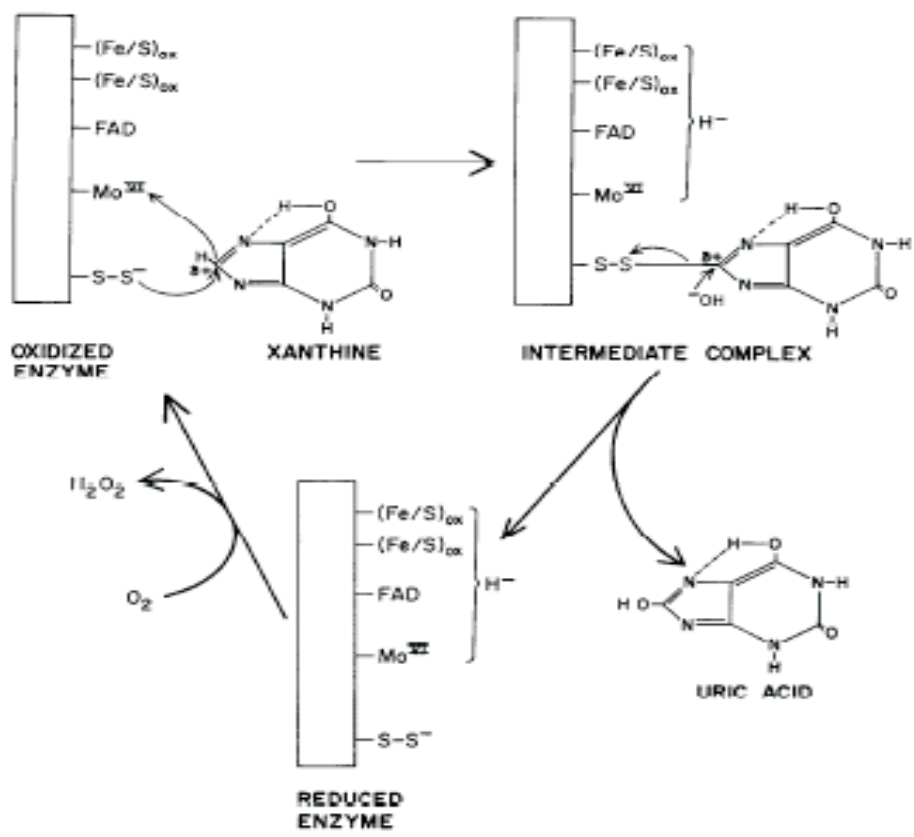

Gambar 1. Mekanisme katalisis oleh gugus persulfid pada xanthine oxidase terhadap xanthine (Edmondson dkk., 1972).

oxidase terhadap xanthine terlihat pada Gambar 1.

\section{Penentuan Penghambatan Aktivitas Xanthine Oxidase}

Penentuan penghambatan aktivitas xanthine oxidase dimulai dengan melakukan orientasi untuk menentukan konsentrasi larutan uji ekstrak etanol (sampel) dan pembanding Allopurinol yang digunakan. Berdasarkan orientasi yang dilakukan, untuk replikasi digunakan larutan uji dengan konsentrasi $10 \mu \mathrm{g} / \mathrm{ml} ; 15 \mu \mathrm{g} / \mathrm{ml}$; dan $20 \mu \mathrm{g} / \mathrm{ml}$, dan larutan Allopurinol dengan konsentrasi $2,5 \mu \mathrm{g} / \mathrm{ml} ; 5,0 \mu \mathrm{g} / \mathrm{ml}$; $7,5 \mu \mathrm{g} / \mathrm{ml}$; dan $10,0 \mu \mathrm{g} / \mathrm{ml}$. Setelah melalui beberapa replikasi, hasil uji penghambatan aktivitas xanthine oxidase dengan atau tanpa bahan uji adalah tertera pada Tabel I Profil penurunan aktivitas xanthine oxidase karena penambahan larutan uji dan pembanding Allopurinol dapat dilihat pada gambar 2 dan gambar 3 .

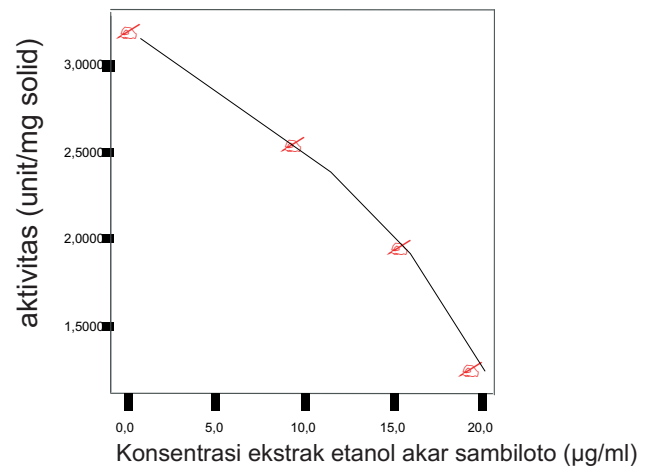

Gambar 2. Grafik hubungan antara konsentrasi ekstrak etanol Akar Sambiloto dengan aktivitas xanthine oxidase dalam mengubah xanthine menjadi asam urat 
Tabel I. Hasil Uji Penghambatan Aktivitas Xanthine Oxidase

\begin{tabular}{|c|c|c|}
\hline \multirow{2}{*}{ Bahan uji } & $\begin{array}{c}\text { Konsentrasi bahan uji } \\
(\boldsymbol{\mu g} / \mathbf{m l})\end{array}$ & $\begin{array}{c}\text { Aktivitas } \pm \text { SD } \\
(\mathbf{u n i t} / \mathbf{m g} \text { solid }\end{array}$ \\
\hline Tanpa bahan uji & - & $3,2204 \pm 0,0246$ \\
\hline \multirow{2}{*}{ Ekstrak etanol } & 10 & $2,4032 \pm 0,0000$ \\
\cline { 2 - 3 } & 15 & $1,9032 \pm 0,0162$ \\
\cline { 2 - 3 } & 20 & $1,1882 \pm 0,0372$ \\
\hline \multirow{2}{*}{ Allopurinol } & 2,5 & $1,8118 \pm 0,0093$ \\
\cline { 2 - 3 } & 5 & $1,5484 \pm 0,0427$ \\
\cline { 2 - 3 } & 7,5 & $1,2366 \pm 0,0336$ \\
\cline { 2 - 3 } & 10 & $0,6774 \pm 0,0279$ \\
\hline
\end{tabular}

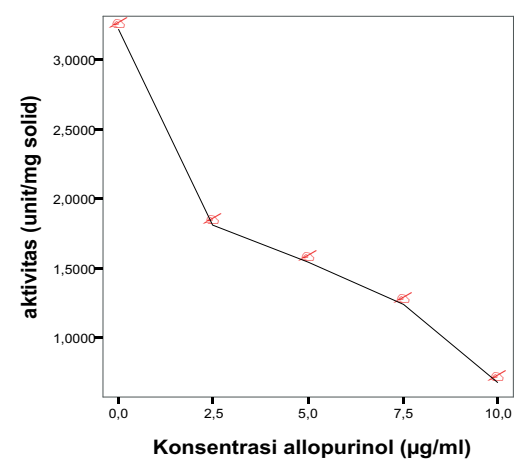

Gambar 3. Grafik hubungan antara konsentrasi Allopurinol terhadap aktifitas xanthine oxidase

Data-data pada kolom aktivitas pada Tabel I menunjukkan adanya penurunan aktivitas xanthine oxidase karena penambahan bahan uji (sampel). Nilai aktivitas enzim xanthine oxidase yang diperoleh dianalisis secara statistik menggunakan program SPSS. Hasil uji Kruskal Wallis menunjukkan adanya perbedaan aktivitas yang signifikan antar kelompok dengan signifikansi $0,000<$ 0,05 . Untuk melihat ada tidaknya perbedaan yang bermakna antar dua perlakuan dilakukan uji Mann-Whitney. Dari uji Mann-Whitney diketahui bahwa semua kelompok yang dibandingkan menunjukkan perbedaan aktivitas yang signifikan. Maka dari hasil analisa SPSS tersebut dapat dilihat bahwa baik pada kelompok kontrol negatif tanpa bahan uji, kelompok sampel larutan uji ekstrak etanol akar Sambiloto konsentrasi 10 $\mu \mathrm{g} / \mathrm{ml} ; 15 \mu \mathrm{g} / \mathrm{ml}$; dan $20 \mu \mathrm{g} / \mathrm{ml}$ dan kelompok kontrol positif (pembanding) Allopurinol dengan konsentrasi 2,5 $\mu \mathrm{g} / \mathrm{ml} ; 5,0 \mu \mathrm{g} / \mathrm{ml} ; 7,5 \mu \mathrm{g} / \mathrm{ml} ;$ dan 10,0 $\mu \mathrm{g} / \mathrm{ml}$ menunjukkan bahwa adanya perbedaan yang signifikan antar kelompok tersebut.

Berdasarkan data-data Tabel I dihitung persen penghambatan (\% inhibisi) untuk tiap-tiap bahan uji dan diperoleh hasil sebagaimana tertera pada Tabel II. Nilai-nilai inhibisi pada Tabel II menunjukkan bahwa semakin besar konsentrasi bahan uji, semakin besar pula persen penghambatannya sehingga aktivitas xanthine oxidase semakin menurun. Berdasarkan data pada tabel II dibuat persamaan regresi linier untuk tiap-tiap bahan uji untuk menentukan nilai $I C_{50}$. Harga $I C_{50}$ menunjukkan besarnya konsentrasi bahan uji yang dapat menghasilkan penghambatan aktivitas enzim xanthine oxidase sebesar $50 \%$. 
Tabel II. Harga \% Inhibisi dari Ekstrak Etanol Akar Sambiloto dan Allopurinol

\begin{tabular}{|c|c|c|}
\hline \multirow{2}{*}{ Bahan uji } & $\begin{array}{c}\text { Konsentrasi bahan uji } \\
(\boldsymbol{\mu} \mathbf{g} / \mathbf{m l})\end{array}$ & Inhibisi (\%) \\
\hline \multirow{2}{*}{ Tanpa } & - & 0 \\
\hline \multirow{2}{*}{ Ekstrak etanol } & 10 & 25,38 \\
\cline { 2 - 3 } & 15 & 40,91 \\
\cline { 2 - 3 } & 20 & 63,11 \\
\hline \multirow{2}{*}{ Allopurinol } & 2,5 & 43,74 \\
\cline { 2 - 3 } & 5 & 51,92 \\
\cline { 2 - 3 } & 7,5 & 61,60 \\
\cline { 2 - 3 } & 10 & 78,97 \\
\hline
\end{tabular}

Berdasarkan nilai $I C_{50}$ pada tabel III dan IV diketahui bahwa nilai $I C_{50}$ ekstrak etanol akar Sambiloto adalah 4 kali lebih besar dibandingkan dengan $I C_{50}$ Allopurinol. Hal ini menunjukkan bahwa daya hambat aktivitas xanthine oxidase oleh ekstrak etanol lebih rendah dibandingkan dengan Allopurinol.
Identifikasi Flavonoid Dalam Ekstrak Etanol Akar Sambiloto

Tetesan kering larutan ekstrak etanol akar Sambiloto dalam etanol pada kertas Whattman, setelah diberi uap amoniak ternyata berwarna kuning. Menurut Robinson (1995) bercak berwarna kuning dapat dijadikan informasi awal keberadaan flavonoid. Timbulnya warna ini disebabkan oleh pembentukan garam dan terbentuknya struktur kuinoid yang memiliki ikatan

Tabel III Persamaan Regresi Linear Dan Nilai $I C_{50}$ Ekstrak Etanol

\begin{tabular}{|c|c|c|c|}
\hline Konsentrasi $(\boldsymbol{\mu g} / \mathbf{m l})$ & Inhibisi (\%) & $\begin{array}{c}\text { Persamaan Regresi } \\
\text { Linear }\end{array}$ & IC $\mathbf{5 0}(\boldsymbol{\mu g} / \mathbf{m l})$ \\
\hline 10 & 25,38 & $\begin{array}{c}\mathrm{Y}=3,773 \mathrm{x}-13,46 \\
\mathrm{R}=0,9948 ; \mathrm{P}<0,05\end{array}$ & 16,82 \\
\hline 15 & 40,91 & & \\
\hline 20 & 63,11 & & \\
\hline
\end{tabular}

Tabel IV. Persamaan Regresi Linear Dan Nilai $I C_{50}$ Allopurinol

\begin{tabular}{|c|c|c|c|}
\hline Konsentrasi $(\mu \mathrm{g} / \mathrm{ml})$ & Inhibisi (\%) & $\begin{array}{c}\text { Persamaan Regresi } \\
\text { Linear }\end{array}$ & $I C_{50}(\mu \mathrm{g} / \mathrm{ml})$ \\
\hline 2,5 & 43,74 & \multirow{4}{*}{$\begin{array}{l}\mathrm{Y}=4,6148 \mathrm{x}+30,215 \\
\mathrm{R}=0,9831 ; \mathrm{P}<0,05\end{array}$} & \multirow[t]{4}{*}{4,29} \\
\hline 5 & 51,92 & & \\
\hline 7,5 & 61,60 & & \\
\hline 10 & 78,97 & & \\
\hline
\end{tabular}




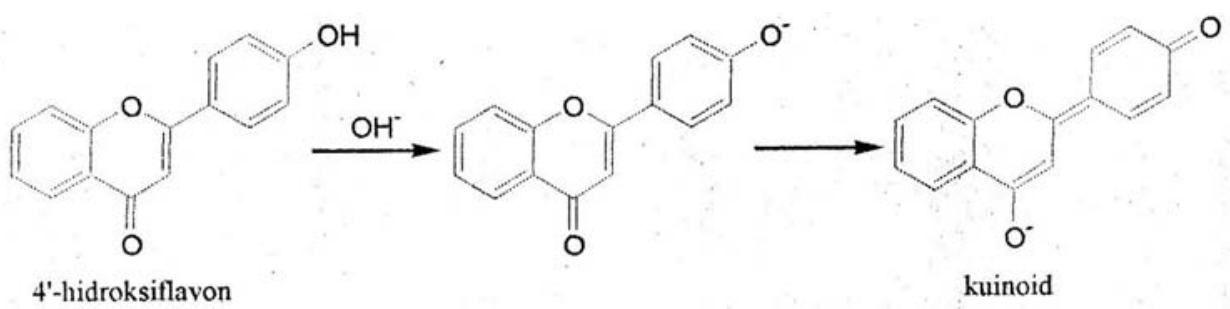

Gambar 4. Reaksi pembentukan struktur kuinoid pada Flavonoid (Robinson, 1995)

rangkap lebih panjang, seperti terlihat pada Gambar 4.

Flavonoid dalam ekstrak etanol selanjutnya diidentifikasi dengan cara pemisahan menggunakan metode kromatografi kertas dengan fase gerak $n$ butanol:asam asetat:air (4:1:5) fase atas. flavon atau flavonol (tersulih pada 3-O mempunyai $5-\mathrm{OH}$ dan mempunyai 4'-OH bebas) (Markham, 1982).

Penurunan aktivitas xanthine oxidase dapat terjadi jika bahan uji mengandung flavonoid terutama yang mempunyai gugus 5,7 dihidroksi pada

Tabel V. Rangkuman Hasil Pengamatan Kromatogram Ekstrak Etanol

\begin{tabular}{|c|c|c|c|c|c|}
\hline \multirow[t]{2}{*}{$\mathrm{Rf}$} & \multicolumn{2}{|c|}{ Warna bercak tanpa $\mathrm{UV}_{366}$} & \multicolumn{2}{|c|}{ Warna bercak dengan $\mathrm{UV}_{366}$} & \multirow{2}{*}{$\begin{array}{l}\text { Perkiraan } \\
\text { flavonoid }\end{array}$} \\
\hline & $\begin{array}{c}\text { Tanpa uap } \\
\mathrm{N}_{\mathrm{H} 3} \\
\end{array}$ & $\begin{array}{c}\text { Dengan uap } \\
\mathrm{NH}_{3}\end{array}$ & $\begin{array}{c}\text { Tanpa uap } \\
\mathrm{NH}_{3}\end{array}$ & $\begin{array}{c}\text { Dengan uap } \\
\mathrm{NH}_{3} \\
\end{array}$ & \\
\hline 0,71 & Kuning & $\begin{array}{l}\text { Kuning } \\
\text { intensif }\end{array}$ & $\begin{array}{c}\text { Lembayung } \\
\text { Gelap }\end{array}$ & Kuning & $\begin{array}{c}\text { Flavon atau } \\
\text { flavonol }\end{array}$ \\
\hline
\end{tabular}

Bercak pada kromatogram selanjutnya dianalisis melalui beberapa perlakuan. Hasil analisis selengkapnya adalah sebagaimana tertera pada Tabel $\mathrm{V}$ dan gambar 5 .

Berdasarkan Tabel V diketahui bahwa bercak pada kromatogram jika dikenakan sinar UV 366nm ternyata berwarna ungu. Bercak tersebut berwarna kuning jika diberi uap amoniak dan dikenakan sinar UV 366nm. Setelah dibandingkan dengan referensi dan berdasarkan fluoresensi bercak sebelum dan sesudah diuapi amoniak, diduga ekstrak etanol akar Sambiloto mengandung senyawa flavonoid golongan

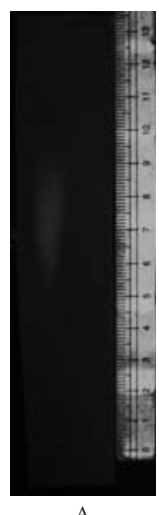

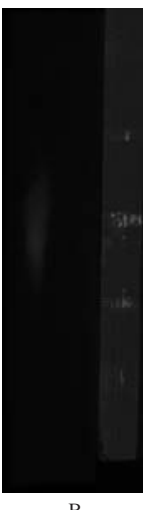

Gambar 5. Hasil kromatografi kertas dengan fase diam kertas Whatman dan fase gerak butanol-asam asetat-air (4:1:5) dengan deteksi UV 366 tanpa uap amoniak (A) dengan uap amoniak (B) 
cincin A (misalnya flavon) yang mirip dengan the six membered ring of xanthine (dalam bentuk enol) (Van Hoorn dkk, 2002). Sedangkan pada penurunan aktivitas xanthine oxidase terjadi pada Allopurinol karena merupakan inhibitor allosterik xanthine oxidase (Lam dkk., 2006), mereduksi gugus reaktif oksidasi-reduksi xanthine oxidase (Massey dkk., 1970).

\section{KESIMPULAN}

Dari hasil penelitian yang telah dilakukan maka dapat disimpulkan ekstrak etanol akar Sambiloto menghambat aktivitas xanthine oxidase dengan nilai $I C_{50} 16,82 \mu \mathrm{g} / \mathrm{ml}$ sedangkan $I C_{50}$ Allopurinol adalah 4,29 $\mu \mathrm{g} / \mathrm{ml}$. Ekstrak etanol akar Sambiloto diduga mengandung flavonoid golongan flavon atau flavonol.

\section{DAFTAR PUSTAKA}

.Cos, P., Ying, L., Calomme, M., J.P., Cimanga, K., Van Poel, B., Pieters, L., Vlietinck., A.J., dan Vanden Berghe, D., 1998, Structure-Activity Relationship and Classification of Flavonoids as Inhibitors of Xanthine Oxidase and Superoxide Scavengers, $J$. Nat. Prod., 61:71-76.

Dalimartha. S. 2001. 96 Resep Tumbuhan Obat untuk Reumatik. 23-32. Penebar Swadaya. Jakarta.

Edmonson, D., Massey, V., Palmer, G., Becham III, L.M., and Elion, G.B., 1972, The Resolution of Active and Inactive Xanthine Oxidase by Affinity Chromatography, J. Biol. Chem., 247(5):1597-1604.
Katzung, B.G., 1995, "Obat Antiinflamasi, Nonsteroid, Analgesik Non Opiat, Obat Yang Digunakan Pada Gout" dalam Farmakologi Dasar dan Klinik edisi ketiga, Penerbit EGC, Jakarta, 492-493.

Lam, L. H., K. Sakaguchi, H. Ukeda, dan M. sawamura, 2006, Flow Injection Determination of Xanthine Oxidase Inhibitory Activity and $1^{\text {st }}$ Application to Food Samples, Anal. Sci., (22) : $105-109$.

Markham, K.R. 1988. Cara Mengidentifikasi Flavonoid, 1-15. Diterjemahkan oleh Kosasih Padmawinata. ITB. Bandung.

Massey, V., Komai, H., and Palmer, G., 1970, On the Mechanism of Inactivation of Xanthine Oxidase by Allopurinol and Other Pyrazolo (3,4-d) pyrimidine, J. Biol, Chem, 245(11): 2837-2844.

Nagao, A., Seki, M., and Kobayashy, H. 1999. Inhibition of Xanthine Oxidase by flavonoid, Biosci. Biotechnol. Biochem. 63(10):1787.

Robinson, T. 1995. Kandungan Organik Tumbuhan Tinggi, Edisi VI, 191-216. Diterjemahkan oleh Kosasih Padmawinata, ITB, Bandung

Setiyaningsih, S., 2003, Isolasi dan Identifikasi Flavonoid Daun Sambiloto (Andrographis paniculata Ness.). Skripsi. Fakultas Farmasi Universitas Ahmad Dahlan. Yogyakarta. 
Sustrani, Lanny, Alam, S., dan Hadibroto, I. 2005. Asam Urat, 25-26. Gramedia Pustaka Utama. Jakarta.

Syamsuhidayat, S.S., Hutapea, J.R. 1991, Inventaris Tanaman Obat Indonesia (I). Departemen Kesehatan Republik Indonesia. Jakarta

Van Hoorn, D.E.C., Nijveldt, R.J., van Leeuwen, P.A.M., Hofman, Z., M'Rabet, L., De Bont, D.B.A., and van Norren, K. 2002. Accurate prediction of xanthine oxidase inhibition based on the structure of flavonoids, Eur. J. Pharmacol., 451: 111-118.

Wijayakusuma, H. Dalimartha, S., Wirian, S.A., 1993, Tanaman Berkhasiat Obat di Indonesia. Jilid II. 117-118. Pustaka Kartini. Jakarta 
